\title{
Simultaneous ventilation of two simulated ARDS patients in COVID-19 pandemic
}

\author{
Danny Epstein ${ }^{1 *}$ (D), Yoav Hoffman², George Dahoud ${ }^{3}$, Aeyal Raz ${ }^{4,5}$ and Asaf Miller ${ }^{6}$
}

\section{Introduction}

The COVID-19 pandemic created a shortage of ventilators in many parts of the world. Models predict that the number of patients that will require a ventilator ranges between 1.4 and 31 patients per available ventilator [1]. Given this potential, numerous groups have proposed modification of ventilator circuit to enable using a single ventilator to support multiple patients. Previous works demonstrated the feasibility of this method in models of healthy lungs, animals, and healthy volunteers [2-4]. In the current study, we used lung models with varying compliances, to investigate whether such simultaneous ventilation is feasible.

\section{Methods}

The inspiratory and expiratory limbs of a Servo Air (Maquet@, Solna, Sweden) ventilator were split using Yconnectors to create two parallel circuits (Fig. 1). These were connected to two test lungs. The same ventilator connected separately to each lung was used to evaluate the compliance of each test lung. The measured compliances were $37 \mathrm{ml} /$ $\mathrm{cmH}_{2} \mathrm{O}$ and $24 \mathrm{ml} / \mathrm{cmH}_{2} \mathrm{O}$ (Fig. 1). These correspond to compliance previously described in COVID-19 patients [5]. We used volume control and pressure control modes set to $1000 \mathrm{~mL}$ tidal volume $\left(\mathrm{T}_{\mathrm{V}} ; 500 \mathrm{~mL}\right.$ per lung) and $20 \mathrm{cmH}_{2} \mathrm{O}$ above positive end-expiratory pressure (PEEP), respectively. We used the respiratory rate of 15 breaths/min and PEEP of $8 \mathrm{cmH}_{2} \mathrm{O}$, and peak pressure alarm was set to $40 \mathrm{cmH}_{2} \mathrm{O}$. We monitored the $\mathrm{T}_{\mathrm{V}}$ and peak pressure of the combined lungs with the ventilator and of each lung separately using a FlowAnalyser PF-300 (Imtmedical@, Buchs, Switzerland). To evaluate the effects of complications such as tube blockage, we recorded the alarms during one lung obstruction.

\section{Results}

Connected to the described configuration, the ventilator did not alarm, and both test lungs expanded. The pressures and volumes measured are shown in Table 1. The combined system compliance was $54.6 \mathrm{ml} / \mathrm{cmH}_{2} \mathrm{O}$ (Fig. 1); not surprisingly, the $\mathrm{T}_{\mathrm{V}} \mathrm{S}$ were unevenly distributed between the test lungs.

During a blockade trial of a single test lung, while ventilated on volume control mode, a "high pressure" alarm was recorded, whereas while performing this trial under pressure control, no alarm was recorded. Ten percent of total $\mathrm{T}_{\mathrm{V}}$ did not reach the lungs due to increased dead space.

\section{Discussion}

The overwhelming number of COVID-19 patients with respiratory failure leads to tremendous efforts to increase ventilation capacity worldwide. Under such conditions, the standards of care for an individual patient may be reduced to allow caring for more patients. However, we found that simultaneous ventilation of patients with different lung compliance prevents appropriate monitoring of pulmonary mechanics, $\mathrm{T}_{\mathrm{V}}$, plateau, and driving pressures. This may preclude safe lung-protective ventilation. As the lung compliance varies greatly in different patients with respiratory failure, simultaneous ventilation of two or more patients with significant differences of their lung physiology may lead to major differences in

* Correspondence: danyep@gmail.com

${ }^{1}$ Internal Medicine "B" department, Rambam Health Care Campus, HaAliya

HaShniya St. 8, 3109601 Haifa, Israel

Full list of author information is available at the end of the article 


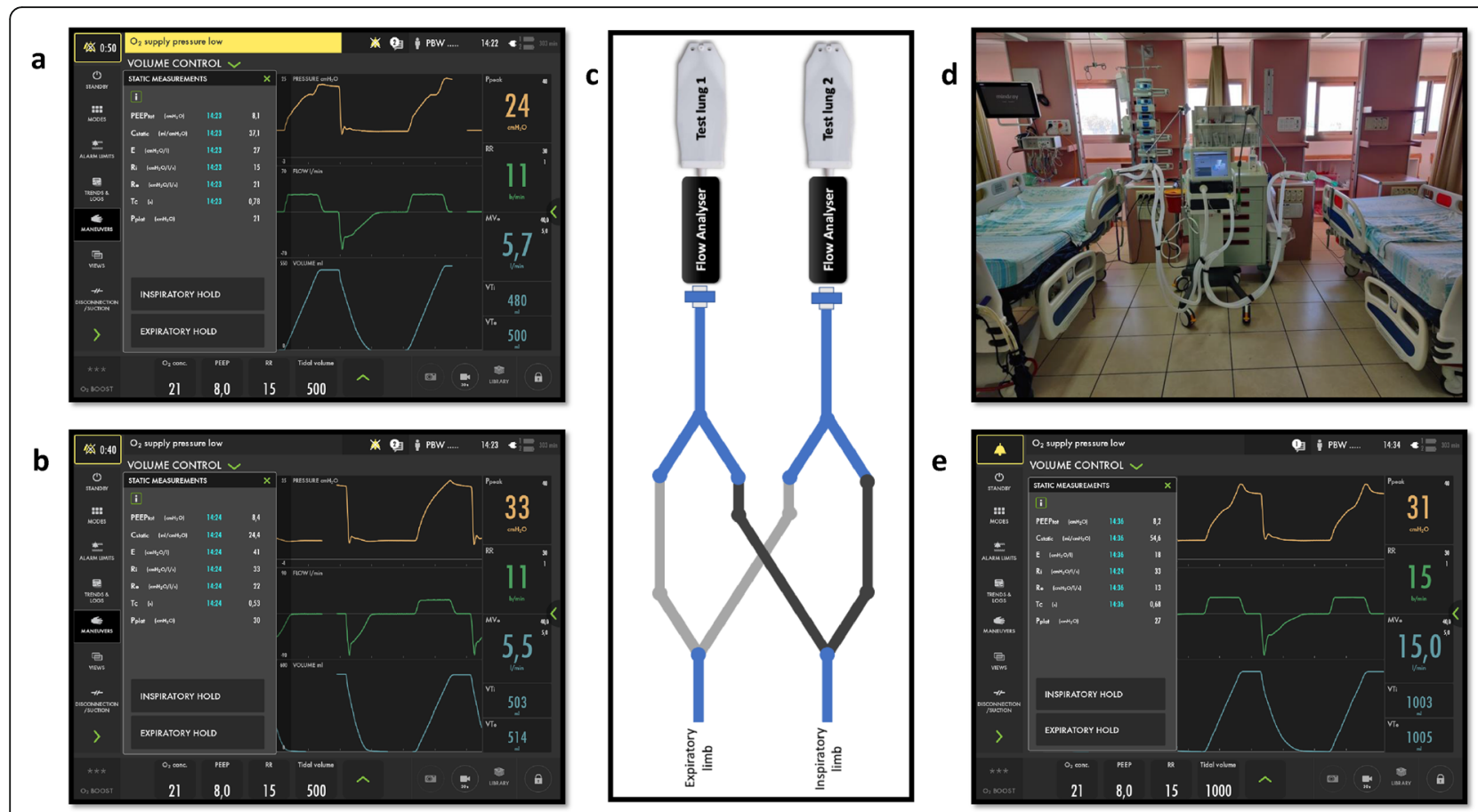

Fig. 1 Simultaneous ventilation model. a Ventilation parameters of high-compliance lung (one lung ventilated). b Ventilation parameters of low-compliance lung (one lung ventilated). c Two-subject ventilator circuit (scheme). d Two-subject ventilator circuit (photography). e Combined ventilation parameters (both lungs connected)

the delivered $\mathrm{T}_{\mathrm{V}} \mathrm{s}$. A possible solution would be to assign patients to common ventilators based on lung compliance. However, this seems very complicated and timeconsuming. Furthermore, even if applied, patients may deteriorate or recover at different rates causing previously similar lungs to drift apart.

Table 1 The combined and the individual pressure and volume characteristics of lung simulators

\begin{tabular}{|c|c|c|c|}
\hline & Combined & $\begin{array}{l}\text { Test lung } 1 \\
\text { (compliance of } \\
37 \mathrm{ml} / \mathrm{cmH}_{2} \mathrm{O} \text { ) }\end{array}$ & $\begin{array}{l}\text { Test lung } 2 \\
\text { (compliance of } \\
24 \mathrm{ml} / \mathrm{cmH}_{2} \mathrm{O} \text { ) }\end{array}$ \\
\hline \multicolumn{4}{|c|}{ Volume control $\left(T_{V}=1000 \mathrm{ml}\right)$} \\
\hline $\begin{array}{l}\text { Tidal volume } \\
\text { (ml) }\end{array}$ & 1000 & 473 & 314 \\
\hline $\begin{array}{l}\text { Positive end- } \\
\text { expiratory pres- } \\
\text { sure }\left(\mathrm{cmH}_{2} \mathrm{O}\right)\end{array}$ & 8 & 8 & 8 \\
\hline $\begin{array}{l}\text { Peak pressure } \\
\left(\mathrm{CmH}_{2} \mathrm{O}\right)\end{array}$ & 30 & 31 & 31 \\
\hline \multicolumn{4}{|c|}{ Pressure control (PC $=20 \mathrm{cmH}_{2} \mathrm{O}$ above PEEP) } \\
\hline $\begin{array}{l}\text { Tidal volume } \\
\text { (ml) }\end{array}$ & 1012 & 475 & 333 \\
\hline $\begin{array}{l}\text { Positive end- } \\
\text { expiratory pres- } \\
\text { sure }\left(\mathrm{cmH}_{2} \mathrm{O}\right)\end{array}$ & 8 & 8 & 8 \\
\hline $\begin{array}{l}\text { Peak pressure } \\
\left(\mathrm{cmH}_{2} \mathrm{O}\right)\end{array}$ & 28 & 21 & 30 \\
\hline
\end{tabular}

Alarm monitoring, a critical safety measure of ventilators, is also impaired, especially when pressure control is used. Although not tested in our experiment, it seems that simultaneous ventilation of multiple patients would necessitate the usage of muscle relaxants as sensing patient effort and trying to synchronize the ventilation to such effort would be pointless under such circumstances.

Based on our preliminary findings, we conclude that simultaneous ventilation of patients with acute respiratory distress syndrome should be abandoned in favor of alternative methods to increase ventilator support capacity. It may be used only temporarily and as a last resort. Our findings support the recommendation of the American College of Chest Physicians [6].

Abbreviations

$T_{\mathrm{V}}$ : Tidal volume; PEEP: Positive end-expiratory pressure

\section{Acknowledgements}

Not applicable.

\section{Authors' contributions}

DE conceived the idea for the study, designed the study, and analyzed the data, performed the statistical analysis, and drafted the manuscript. YH designed the study, collected and analyzed the data, and drafted the manuscript. GD designed the study model, collected the data, reviewed the manuscript, and approved the final manuscript as submitted. AR conceived the idea for the study, designed the study, drafted the manuscript, and approved the final manuscript as submitted. AM conceived the idea for the study, designed the study, analyzed the data, critically reviewed and revised the manuscript, and approved the final manuscript as submitted. The authors read and approved the final manuscript. 


\section{Funding}

This work was supported by the United States-Israel Binational Science Foundation (BSF) Grant 201732 to AR.

\section{Availability of data and materials}

All data generated or analyzed during this study are included in this published article.

\section{Ethics approval and consent to participate}

Our study does not involve human participants; under Israeli law, institutional review board approval was not required for this report.

\section{Consent for publication}

Not applicable.

\section{Competing interests}

AR is a consultant for and receives funding from Medtronic (unrelated to this project). The other authors declare no competing interests.

\section{Author details}

${ }^{1}$ Internal Medicine "B" department, Rambam Health Care Campus, HaAliya HaShniya St. 8, 3109601 Haifa, Israel. ${ }^{2}$ Pediatric Intensive Care unit, Galilee Medical Center, Nahariya, Israel. ${ }^{3}$ Critical Care division, Rambam Health Care Campus, Haifa, Israel. ${ }^{4}$ Department of Anesthesiology, Rambam Health Care Campus, Haifa, Israel. ${ }^{5}$ Ruth and Bruce Rappaport Faculty of Medicine, Technion, Haifa, Israel. ${ }^{6}$ Medical Intensive Care unit, Rambam Health Care

Campus, Haifa, Israel

Received: 14 April 2020 Accepted: 1 May 2020

Published online: 11 May 2020

\section{References}

1. Truog RD, Mitchell C, Daley GQ. The toughest triage - allocating ventilators in a pandemic. N Engl J Med. 2020. https://doi.org/10.1056/NEJMp2005689. [Epub ahead of print].

2. Smith R, Brown JM. Simultaneous ventilation of two healthy subjects with a single ventilator. Resuscitation. 2009:80:1087.

3. Neyman G, Irvin CB. A single ventilator for multiple simulated patients to meet disaster surge. Acad Emerg Med. 2006;13:1246-9.

4. Paladino L, Silverberg M, Charchaflieh JG, Eason JK, Wright BJ, Palamidessi N, et al. Increasing ventilator surge capacity in disasters: ventilation of four adult-human-sized sheep on a single ventilator with a modified circuit. Resuscitation. 2008;77:121-6.

5. Bhatraju PK, Ghassemieh BJ, Nichols M, Kim R, Jerome KR, Nalla AK, et al. COVID-19 in critically ill patients in the Seattle region - case series. N Engl J Med. 2020. https://doi.org/10.1056/NEJMoa2004500. [Epub ahead of print].

6. Joint Statement on Multiple Patients per Ventilator - American College of Chest Physicians. Available from: http://www.chestnet.org/News/PressReleases/2020/03/Joint-Statement-on-Multiple-Patients-per-Ventilator. [cited 2020 Apr 5].

\section{Publisher's Note}

Springer Nature remains neutral with regard to jurisdictional claims in published maps and institutional affiliations. 